(2) Open Access Full Text Article

\title{
Assessment of effectiveness of percutaneous adhesiolysis and caudal epidural injections in managing post lumbar surgery syndrome: 2-year follow-up of a randomized, controlled trial
}

\author{
This article was published in the following Dove Press journal: \\ Journal of Pain Research \\ 19 December 2012 \\ Number of times this article has been viewed
}

\author{
Laxmaiah Manchikanti ${ }^{1,2}$ \\ Vijay Singh ${ }^{3}$ \\ Kimberly A Cash' \\ Vidyasagar Pampati' \\ 'Pain Management Center \\ of Paducah, Paducah, KY, ${ }^{2}$ Department \\ of Anesthesiology and Perioperative \\ Medicine, University of Louisville, \\ Louisville, KY, ${ }^{3}$ Pain Diagnostics \\ Associates, Niagara, WI, USA
}

\begin{abstract}
Background: The literature is replete with evaluations of failed surgery, illustrating a $9.5 \%-25 \%$ reoperation rate. Speculated causes of post lumbar surgery syndrome include epidural fibrosis, acquired stenosis, recurrent disc herniation, sacroiliac joint pain, and facet joint pain among other causes.
\end{abstract}

Methods: Patients $(n=120)$ were randomly assigned to two groups with a 2-year follow-up. Group I (control group, $\mathrm{n}=60$ ) received caudal epidural injections with catheterization up to S3 with local anesthetic (lidocaine $2 \%, 5 \mathrm{~mL}$ ), nonparticulate betamethasone $(6 \mathrm{mg}, 1 \mathrm{~mL}$ ), and $6 \mathrm{~mL}$ of $0.9 \%$ sodium chloride solution. Group II (intervention group, $\mathrm{n}=60$ ) received percutaneous adhesiolysis of the targeted area, with targeted delivery of lidocaine $2 \%(5 \mathrm{~mL})$, $10 \%$ hypertonic sodium chloride solution $(6 \mathrm{~mL})$, and nonparticulate betamethasone $(6 \mathrm{mg})$. The multiple outcome measures included the Numeric Rating Scale, the Oswestry Disability Index 2.0, employment status, and opioid intake with assessments at 3, 6, 12, 18, and 24 months posttreatment. Primary outcome was defined as 50\% improvement in pain and Oswestry Disability Index scores.

Results: Significant improvement with at least $50 \%$ relief with pain and improvement in functional status was illustrated in $82 \%$ of patients at the 2-year follow-up in the intervention group compared to $5 \%$ in the control group receiving caudal epidural injections. The average number of procedures over a period of 2 years in Group II was $6.4 \pm 2.35$ with overall total relief of approximately 78 weeks out of 104 weeks.

Conclusion: The results of this study show significant improvement in $82 \%$ of patients over a period of 2 years with an average of six to seven procedures of 1-day percutaneous adhesiolysis in patients with failed back surgery syndrome.

Keywords: epidural adhesions, epidural steroid injections, epidural fibrosis

\section{Introduction}

Comparative effectiveness evidence from the Spine Patients Outcomes Research Trial showed significant improvement in patients who had surgical interventions compared to conservative treatment modalities. ${ }^{1}$ However, this trial also showed a reoperation rate of $4 \%$ at 1 year and $10 \%$ at 4 years. In addition, the literature is replete with numerous evaluations illustrating a $9.5 \%-25 \%$ reoperation rate with a substantial proportion of patients suffering from post lumbar surgery syndrome. ${ }^{2-11}$ There has been a substantial increase in surgical procedures in the US to treat low back pain. In addition to decompression surgery, spinal fusion has become a major
Correspondence: Laxmaiah Manchikanti 283I Lone Oak Road, Paducah, KY 42003, USA

Tel + I 2705548373 ext I0 I

Fax +I 2705548987

Email drIm@thepainmd.com 
industry in US medicine accounting for almost $\$ 9$ billion in total revenue in $2007 .{ }^{12}$ It has been described that the surge in spinal fusion has occurred in a manner that is out of sync with scientific evidence regarding the risks and benefits of this form of surgery. Martin et al showed a mean reoperation rate of $6.1 \%$ at 1 year and $13.2 \%$ at 4 years, higher than the Spine Patients Outcomes Research Trial reoperation benchmarks. ${ }^{13}$ Deyo et al also showed that the probability of repeat surgery at 4 years was $10.6 \%-17.2 \%$ in patients undergoing operations for lumbar spinal stenosis. ${ }^{14}$ While there are multiple causes that require revision surgery, many causes do not require repeat surgery and may be managed by interventional techniques. ${ }^{15-19}$

The unremitting pain and disability in the low back and lower extremities following lumbar spine surgery has been hypothesized to be secondary to multiple causes including epidural fibrosis, sacroiliac joint pain, disc herniation, discogenic pain, spinal stenosis, arachnoiditis, and facet joint pain, along with inappropriate surgery. ${ }^{7-11,19,20}$ While the debate continues on epidural fibrosis as being the major cause of pain after lumbar spine surgery with multiple authors describing lack of association, ${ }^{21-23}$ Ross et al found that patients with extensive epidural fibrosis were 3.2 times more likely to experience recurrent radicular pain than those with less scarring. ${ }^{8}$ In addition, experimental studies have provided electrophysiological evidence of neurologic disturbances caused by peridural scar formation. ${ }^{24} \mathrm{~A}$ multitude of other abnormalities including mechanical tethering of nerve roots secondary to epidural fibrosis in the vertebral canal, ${ }^{25,26}$ disturbances in blood flow, ${ }^{27}$ and expression of proinflammatory cytokines causing irritation of exposed dorsal root ganglion and triggering painful responses have been described. ${ }^{28}$ It also has been shown that osteopontin is a major player in the formation of epidural fibrosis and a mark-up dorsal root ganglia response to peridural scar formation. ${ }^{24}$ In addition, experimental evidence also has implicated paraspinal muscle spasms, tail contractures, pain behaviors, tactile allodynia, epidural and perineural scarring, and nerve root adherence to the underlying discs and pedicle in animal models. ${ }^{29,30}$

Among the nonsurgical interventions in managing chronic persistent pain of post lumbar surgery syndrome, epidural steroid injections and percutaneous adhesiolysis are two of the most commonly utilized interventions. ${ }^{15,16,19,31-40}$ However, epidural steroid injections provided significant improvement in only $53 \%$ and $59 \%$ of the patients at the 12 -month follow-up in a randomized double-blind controlled trial with significant improvement of $50 \%{ }^{34}$ Thus, as many as $50 \%$ of patients continue to have significant pain even after fluoroscopically directed epidural injections have been utilized. Consequently, percutaneous adhesiolysis as a treatment modality in patients after the failure of conservative management including fluoroscopic epidural injections has been recommended. ${ }^{15,41,42}$ In a recent systematic review, Helm et al assessed the available literature rigorously utilizing quality assessment and clinical relevance criteria in 15 studies, of which four randomized controlled trials and one observational study met the inclusion criteria. ${ }^{15}$ They concluded that there is fair evidence that percutaneous adhesiolysis is effective in relieving low back or leg pain caused by post lumbar surgery syndrome. However, the use of epidural steroid injections and adhesiolysis have been met with skepticism, facing significant criticism in post lumbar surgery syndrome and spinal stenosis due to an alleged lack of evidence, even though supporters have described it otherwise. . $^{15,19,34,40-49}$ Thus, there have been multiple studies published showing the effectiveness of percutaneous adhesiolysis in recalcitrant low back pain. In fact, a 1-year follow-up of a randomized active-controlled trial evaluating percutaneous adhesiolysis and caudal epidural steroid injections in managing post lumbar surgery syndrome showed percutaneous adhesiolysis as being effective in $73 \%$ of patients at the 1 -year follow-up. ${ }^{35}$ This study was designed to evaluate the effectiveness of percutaneous epidural adhesiolysis in patients with chronic low back and lower extremity pain in post lumbar surgery syndrome and to compare it with fluoroscopically directed caudal epidural steroid injections. It reported the results of a 1-year follow-up.

The current report describes a 2-year follow-up of 120 patients regarding the role of percutaneous adhesiolysis in comparison to caudal epidural injections in those patients who have failed conservative management including caudal epidural injections in post lumbar surgery syndrome. The previous report of a 1-year follow-up has been published. ${ }^{35}$

\section{Methods}

The study was conducted in an interventional pain management practice, a specialty referral center, in a private practice setting in the US, with the approval of the Institutional Review Board and registration of the protocol with the US Clinical Trial Registry (NCT00370994). The current study was performed based on Consolidated Standards of Reporting Trials (CONSORT) guidelines. ${ }^{50}$ The study was conducted with the internal resources of the practice without external funding from industry or others. 


\section{Participants}

One-hundred and twenty patients were recruited from a single interventional pain management practice and were assigned to one of two groups. The Institutional Review Board-approved protocol and informed consent described in detail all aspects of the study and withdrawal process.

Group I (or control group) with 60 patients assigned received caudal epidural injections. Group II patients received percutaneous adhesiolysis in the targeted area with lidocaine, $10 \%$ sodium chloride solution, and nonparticulate betamethasone.

\section{Preenrollment evaluation}

Preenrollment of all the patients included demographic data; medical and surgical history and coexisting disease(s); radiologic investigations; physical examination; pain rating score using the Numeric Rating Scale (NRS); functional assessment using the Oswestry Disability Index (ODI) 2.0; work status; and opioid intake.

\section{Inclusion and exclusion criteria}

The first inclusion criteria was that all patients had previously undergone lumbar surgery with or without fusion at least 6 months prior to enrollment with chronic function-limiting low back pain with or without lower extremity pain of at least 6 months duration. The second criteria was that all of them had failed conservative management including, but not limited to, physical therapy, chiropractic manipulation, exercises, drug therapy, bed rest, and fluoroscopically directed caudal or transforaminal epidural injections. Additionally, only patients over the age of 18 years and patients who were able to understand the study protocol, provide voluntary written informed consent, and participate in outcome measurements were included.

Exclusion criteria included pain of facet joint origin or sacroiliac joint origin with controlled diagnostic blocks, heavy opioid use or unstable opioid use or $>400 \mathrm{mg}$ morphine equivalents daily, uncontrolled psychiatric disorders, uncontrolled medical illness, and any other conditions that could interfere with the interpretation of the outcome assessments, pregnant or lactating women, and patients with a history or potential for adverse reactions to lidocaine, betamethasone, and sodium chloride solution either $0.9 \%$ or $10 \%$.

\section{Description of interventions}

All procedures were performed by one physician in a sterile operating room under sterile conditions utilizing fluoroscopy and an RK needle and a Racz catheter, 19 gauge Bevi-STF
(Epimed International, Farmers Branch, TX, USA). The procedure was performed with appropriate preparation, which included intravenous access, antibiotic administration, and appropriate sedation as desired.

The procedure included passage of an RK needle into the sacral hiatus and epidural space under intermittent fluoroscopy up to S3, with performance of a lumbar epidurogram utilizing approximately $5 \mathrm{~mL}$ of contrast with Omnipaque $^{\mathrm{TM}} 240$ (GE Healthcare, Little Chalfont, UK). In Group I, a catheter was advanced through the RK needle up to $\mathrm{S} 3$ and additional Omnipaque $240,3-5 \mathrm{~mL}$ was injected. Following this, $5 \mathrm{~mL}$ of $2 \%$ preservative free Xylocaine ${ }^{\circledR}$ was injected into the epidural space through the catheter.

In Group II after performing the epidurogram, a Racz catheter was passed to the area of the filling defects to the site of pathology as determined by magnetic resonance imaging, computed tomography, or symptomatology. Following the adhesiolysis, the final position was achieved in the epidural space laterally and ventrally as feasible. Following this, 3-5 $\mathrm{mL}$ of contrast was injected to confirm the position of the catheter along with filling of the defective area and nerve roots. If there was no subarachnoid, intravascular, or other extradural filling, and satisfactory filling was obtained with epidural and targeted nerve root filling, $5 \mathrm{~mL}$ of $2 \%$ preservative free Xylocaine was injected either in repeat doses of two or three or as a single dose based on whether or not the patient had a fusion.

Following the completion of the injections, the catheter was taped utilizing bioocclusive dressing in all patients.

In the recovery room, the patients were observed for any motor weakness. If no such weakness was observed and no other complications were noted after 10-15 minutes of lidocaine administration, $6 \mathrm{~mL}$ of normal saline in Group I or $10 \%$ sodium chloride solution in Group II were injected in two divided doses of $3 \mathrm{~mL}$ each. This was followed by an injection of $6 \mathrm{mg}$ of nonparticulate betamethasone and flushing of the catheter with $1 \mathrm{~mL}$ of sodium chloride solution, followed by its removal in both groups.

\section{Additional interventions}

Repeat percutaneous adhesiolysis procedures were provided after at least 3 months based on the response to the prior injection as evaluated by improvement in physical and functional status and also deterioration of pain relief below $50 \%$.

All patients underwent the treatments as assigned. A patient was unblinded on request or if an emergency situation existed. If a patient required additional procedures, they were provided based on the response to the previous procedure. If the patient 
chose to be unblinded, they were considered as withdrawn and other treatments were provided. Patients who were nonresponsive, but continued with conservative management were followed without further procedures, but with only medical and conservative management.

\section{Cointerventions}

Patients receiving opioids and nonopioid analgesics, adjuvant analgesics, and therapeutic exercise programs continued all the interventions. There was no specific or additional intervention provided other than the study procedure. Medications were adjusted as medically necessary. All patients continued previously directed therapeutic exercise programs as well as their work, if they were working.

\section{Objectives}

The objectives of this study were to evaluate the effectiveness of percutaneous adhesiolysis in managing chronic low back and/or lower extremity pain and providing effective and long-lasting pain relief with functional status improvement for patients with post lumbar surgery syndrome, and to compare the results with fluoroscopically directed caudal epidural injections.

\section{Outcomes}

Various outcome measures utilized included NRS (zero to ten pain scale), ODI 2.0 (zero to 50 scale), employment status, and opioid intake in terms of daily intake or morphine equivalence. Assessments were carried out at 3, 6, 12, 18, and 24 months posttreatment. The value and validity of NRS and ODI have been reported. ${ }^{51,52}$

A strong measure of improvement with significant pain relief of $50 \%$ or more and a reduced disability status with reduction of ODI scores of $50 \%$ or more was utilized as criteria for the primary outcome. ${ }^{34,36-38,53-65}$

The opioid intake was measured in terms of morphine equivalency. ${ }^{66}$

Employment and work status were categorized into various subgroups with those who were employable, retired, aged over 65 years, or housewife with no desire to work outside the home. However, participants who - because of pain - were unemployed, on sick leave, or employed but laid off were considered employable. Thus, employment statistics were based on employability.

\section{Sample size}

Sample size was calculated based on the reduction of NRS and ODI scores. A 25\% clinical difference change of 1.15 (d) was set from a previous study. ${ }^{67}$ With a standard deviation $(\sigma)$ of the NRS of $2.3, \delta=\mathrm{d} / \sigma, \delta=0.50$, to achieve an alpha of 0.05 and beta of 0.20 with $80 \%$ power, ${ }^{68} 60$ patients in each group of the trial were required. One-hundred patients in each group would provide $95 \%$ power (ie, alpha and beta of 0.05$)$.

\section{Randomization}

From a total of 120 patients, 60 patients were randomly assigned into each group.

\section{Sequence randomization}

Computer generated random allocation sequence by simple randomization was used for randomization purposes.

\section{Allocation concealment}

The operating room nurse assisting with the procedure carried out the randomization. The nurse also prepared the drugs appropriately.

\section{Implementation}

Participants were invited to enroll in the study if they met the inclusion criteria. Inclusion was carried out by one of the three study coordinators enrolling the participants and assigning them into respective groups.

\section{Blinding/masking}

Participants and the physician administering the intervention were blinded to the group assignment. The blinding was assured by mixing the patients with other patients receiving routine treatment and not informing the physician performing the procedure of the inclusion of the patient in the study. However, blinding was considered inadequate in patients in Group I as the physician performing the procedure was informed of Group I as it was necessary to position the catheter at S3, which was not a usual practice. However, the drugs injected during the procedure were not revealed to other staff members.

\section{Statistical methods}

Data analyses were carried out using SPSS version 9.01 (SPSS Inc, Chicago, IL). For categorical and continuous data comparison, Chi-squared statistic, Fisher's exact test, one-way analysis of variance, Student's $t$-test, and paired $t$-test were the statistical analyses used. Because the outcome measures of the participants were measured at six time points, repeated measures analysis of variance were performed with post hoc analysis. A $P$-value of less than 0.05 was considered significant. 


\section{Intent-to-treat analysis}

An intent-to-treat-analysis was performed. Either the last follow-up data or initial data were utilized in the patients who dropped out of the study or for whom no other data were available.

A sensitivity analysis with changes in the NRS was performed utilizing the last follow-up score, best case scenario, and worst case scenario. If there were no significant differences, the intention-to-treat analysis with the last follow-up visit was used.

\section{Results}

Figure 1 illustrates the participant flow.

\section{Recruitment}

The recruitment period lasted from January 2006 to June 2010.

\section{Baseline data}

Table 1 illustrates baseline demographic and clinical characteristics of 120 patients. All the demographic and clinical data were similar for both groups.

\section{Therapeutic procedural characteristics}

Table 2 illustrates the therapeutic procedural characteristics with average pain relief per procedure and average number of procedures performed with back and leg pain relief described separately. Average pain relief per procedure was approximately 5 weeks in Group I, whereas it was 12 weeks in Group II - statistically significant from Group I. The average number of procedures for 2 years was 2.4 in Group I and 6.4 in Group II. Average total relief per year was approximately 13 weeks in Group I and 40 weeks in Group II. Average total relief for 2 years was approximately 15 weeks in Group I and 78 weeks

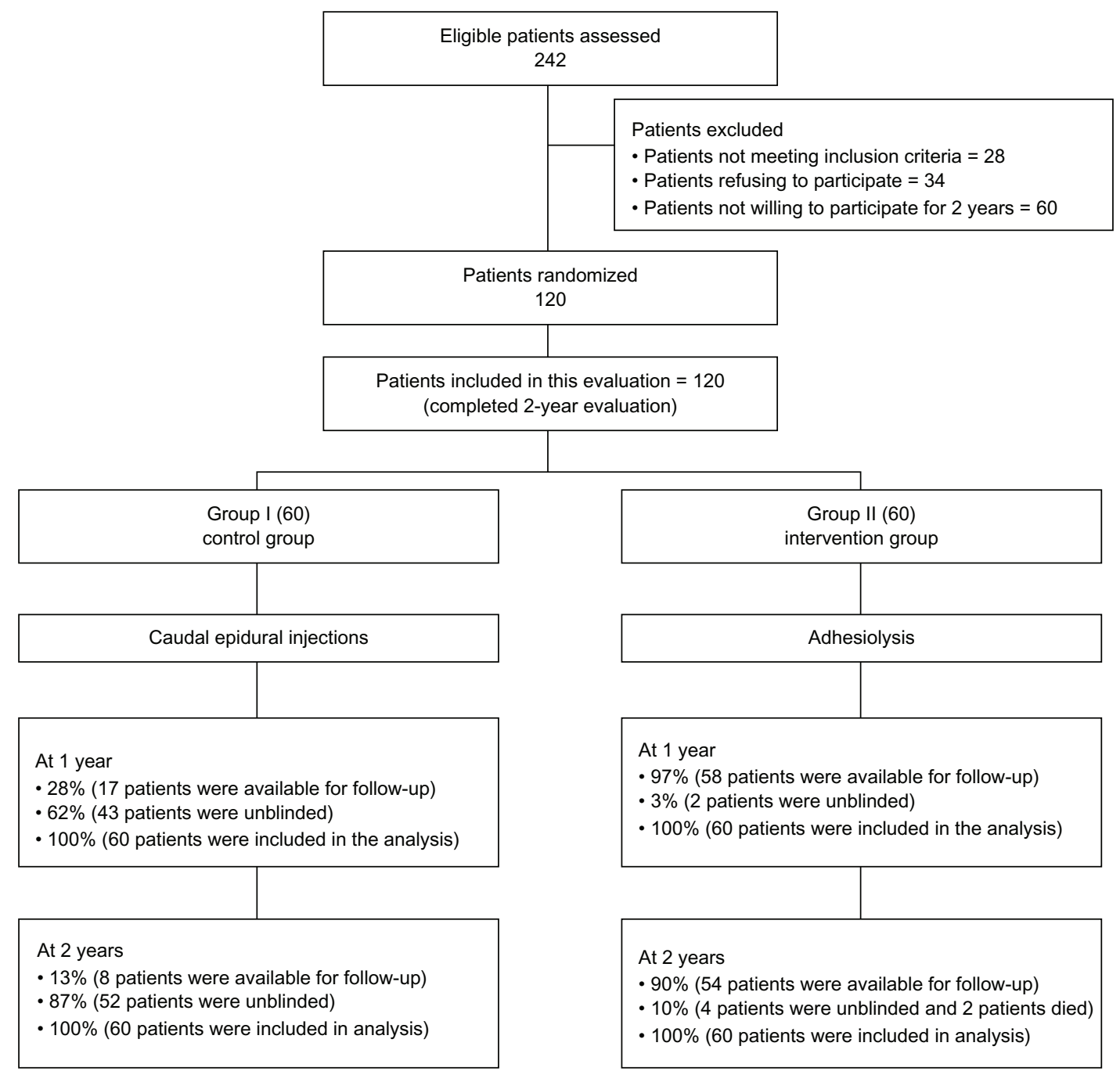

Figure I Schematic presentation of patient flow at 2-year follow-up. 
Table I Demographic characteristics and clinical data

\begin{tabular}{|c|c|c|c|}
\hline & $\begin{array}{l}\text { Group I } \\
(n=60)\end{array}$ & $\begin{array}{l}\text { Group II } \\
(n=60)\end{array}$ & $P$-value \\
\hline \multicolumn{4}{|l|}{ Gender } \\
\hline Male & $42 \%(25)$ & $42 \%(25)$ & \multirow{2}{*}{1.00} \\
\hline Female & $58 \%(35)$ & $58 \%(35)$ & \\
\hline \multicolumn{4}{|l|}{ Age } \\
\hline Mean \pm standard deviation & $52 \pm 13.9$ & $52 \pm 12.5$ & 0.962 \\
\hline \multicolumn{4}{|l|}{ Height (inches) } \\
\hline Mean \pm standard deviation & $67 \pm 4.3$ & $67 \pm 4.0$ & 0.807 \\
\hline \multicolumn{4}{|l|}{ Weight (lbs) } \\
\hline Mean \pm standard deviation & $185 \pm 44.0$ & $178 \pm 50.1$ & 0.458 \\
\hline \multicolumn{4}{|c|}{ Duration of pain (months) } \\
\hline Mean \pm standard deviation & $186 \pm 121.7$ & $196 \pm 109.4$ & 0.642 \\
\hline \multicolumn{4}{|l|}{ Mode of onset of pain } \\
\hline Nontraumatic & $55 \%(33)$ & $57 \%(34)$ & \multirow{2}{*}{0.540} \\
\hline Traumatic & $45 \%(27)$ & $43 \%(26)$ & \\
\hline \multicolumn{4}{|l|}{ Back pain distribution } \\
\hline Bilateral & $72 \%(43)$ & $65 \%(39)$ & \multirow{2}{*}{0.40} \\
\hline Left or right & $28 \%(17)$ & $35 \%(2 I)$ & \\
\hline \multicolumn{4}{|l|}{ Leg pain distribution } \\
\hline Bilateral & $39 \%(23)$ & $35 \%(2 I)$ & \multirow{2}{*}{0.926} \\
\hline Left or right & $61 \%(37)$ & $65 \%(39)$ & \\
\hline \multicolumn{4}{|l|}{ Pain ratio } \\
\hline Back pain only & $2 \%(I)$ & $0 \%$ & \multirow{4}{*}{0.46} \\
\hline Back worse than leg & $63 \%(38)$ & $57 \%(34)$ & \\
\hline Leg worse than back & $3 \%(2)$ & $8 \%(5)$ & \\
\hline Both equal & $32 \%(19)$ & $35 \%(2 I)$ & \\
\hline \multicolumn{4}{|c|}{ Surgical history (number of interventions) } \\
\hline One & $50 \%(30)$ & $47 \%(28)$ & \multirow{4}{*}{0.603} \\
\hline Two & $30 \%(18)$ & $23 \%(14)$ & \\
\hline Three & $10 \%(6)$ & $17 \%(10)$ & \\
\hline More than three & $10 \%(6)$ & $13 \%(8)$ & \\
\hline
\end{tabular}

Note: Unless otherwise stated, data expressed as \% (n).

in Group II. There were significant differences with average relief and total relief.

\section{Outcomes}

\section{Pain relief and functional assessment}

Table 3 presents the results of the repeated measures analysis. There were significant differences in pain and function between both groups, there were also significant differences from baseline to various measurement points.

\section{Combined pain relief and functional status}

As shown in Figure 2, the proportion of patients with significant reduction (greater than 50\%) in NRS scores and ODI showed significant differences between both groups. This figure illustrates significant pain relief and improvement in functional status in $70 \%$ of the patients in Group II at the end of 1 year and $82 \%$ and the end of 2 years, whereas it was $5 \%$ as the end of 1 year and 2 years in the control group.

\section{Employment characteristics}

Employment characteristics are illustrated in Table 4. There was no change in employment status. There were only twelve patients eligible for employment in Group I and five patients in Group II, illustrating the difficulty of postsurgery patients as the majority of them are disabled.

\section{Opioid intake}

Opioid intake characteristics illustrate a significant decrease from the baseline; however, there were no significant differences between the groups (Table 5).

\section{Changes in weight}

Changes in body weight are illustrated in Table 6 with significant changes observed among the groups at baseline and 2-year follow-up.

\section{Adverse events}

There were no major adverse events reported. However, there were seven subarachnoid entries in the adhesiolysis group and two patients developed postoperative weakness lasting for a few hours.

\section{Discussion}

The results of the first large, randomized, active-controlled trial of the effectiveness of percutaneous adhesiolysis in comparison with caudal epidural injections in post lumbar surgery syndrome patients in managing chronic low back and/or lower

Table 2 Therapeutic procedural characteristics with procedural frequency, average relief per procedure, and average total relief in weeks over a period of I year and 2 years

\begin{tabular}{|c|c|c|c|c|}
\hline & \multicolumn{2}{|l|}{ Back pain } & \multicolumn{2}{|l|}{ Leg pain } \\
\hline & $\begin{array}{l}\text { Group I } \\
(n=60)\end{array}$ & $\begin{array}{l}\text { Group II } \\
(n=60)\end{array}$ & $\begin{array}{l}\text { Group I } \\
(n=59)\end{array}$ & $\begin{array}{l}\text { Group II } \\
(n=58)\end{array}$ \\
\hline Average number of procedures per year & $2.2 * \pm 1.08$ & $3.5 \pm 1.03$ & $2.2 * \pm 1.09$ & $3.4 \pm 1.03$ \\
\hline Average number of procedures per 2 years & $2.4^{*} \pm 1.44$ & $6.4 \pm 2.35$ & $2.4^{*} \pm 1.45$ & $6.4 \pm 2.35$ \\
\hline Average relief per procedure (weeks) & $4.9 * \pm 4.00$ & $11.7 \pm 2.97$ & $5.1 * \pm 3.90$ & $11.5 \pm 3.34$ \\
\hline Average total relief per year (weeks) & $13.2 * \pm 14.20$ & $40.7 \pm 14.92$ & $|2.9 * \pm| 3.7 \mid$ & $39.7 \pm 15.87$ \\
\hline Average total relief per 2 years (weeks) & $14.8^{*} \pm 19.77$ & $78.5 \pm 32.36$ & $15.0 * \pm 19.77$ & $77.7 \pm 33.07$ \\
\hline
\end{tabular}

Note: *Significant difference with Group II $(P<0.05)$. 
Table 3 Comparison of the numeric rating scale for pain and Oswestry Disability Index score summaries at six time points

\begin{tabular}{|c|c|c|c|c|}
\hline \multirow[t]{3}{*}{ Time points } & \multicolumn{4}{|c|}{ Mean \pm standard deviation } \\
\hline & \multicolumn{2}{|c|}{ Numeric pain rating score } & \multicolumn{2}{|c|}{ Oswestry Disability Index } \\
\hline & $\begin{array}{l}\text { Group I } \\
(n=60)\end{array}$ & $\begin{array}{l}\text { Group II } \\
(n=60)\end{array}$ & $\begin{array}{l}\text { Group I } \\
(n=60)\end{array}$ & $\begin{array}{l}\text { Group II } \\
(n=60)\end{array}$ \\
\hline Baseline & $7.9 \pm 0.8$ & $8.1 \pm 0.8$ & $28.6 \pm 4.1$ & $31.2 \pm 4.1$ \\
\hline 3 months & $4.9 * \pm 1.6$ & $3.4^{*} \pm 0.8$ & $20.2 * \pm 6.6$ & $15.2^{*} \pm 4.1$ \\
\hline 6 months & $5.8^{*} \pm 1.5$ & $3.7^{*} \pm 1.1$ & $22.3^{*} \pm 6.1$ & $15.2 * \pm 5.2$ \\
\hline 12 months & $6.1 * \pm 1.4$ & $4.0 * \pm 1.2$ & $23.3^{*} \pm 5.8$ & $15.8^{*} \pm 5.6$ \\
\hline 18 months & $6.1 * \pm 1.4$ & $3.6^{*} \pm 1.2$ & $23.3 \pm 5.7$ & $14.6 \pm 4.6$ \\
\hline 24 months & $6.2 * \pm 1.4$ & $3.6 * \pm 1.1$ & $23.2 \pm 6.7$ & $13.9 \pm 5.1$ \\
\hline Group difference & \multicolumn{2}{|c|}{0.001} & \multicolumn{2}{|c|}{0.001} \\
\hline Baseline versus follow-up points & \multicolumn{2}{|c|}{0.001} & \multicolumn{2}{|c|}{0.001} \\
\hline Group by time interaction ${ }^{\#}$ & \multicolumn{2}{|c|}{0.001} & \multicolumn{2}{|c|}{0.001} \\
\hline
\end{tabular}

Notes: *Significant difference with baseline values $(P<0.05)$; "there was significant difference between groups at 3 months, 6 months, 12 months, 18 months, and 24 months.

extremity pain with a 2-year follow-up in 120 patients showed clinically meaningful and significant improvement in pain and functional status at the end of 1 year and 2 years in the intervention group compared to the control or caudal epidural group, in patients who have already failed conservative management and fluoroscopically directed caudal epidural injections. The results of this practical evaluation performed in a nonacademic private practice setting simulating practice patterns illustrate that in carefully selected patients not experiencing facet joint or sacroiliac joint pain, those who have failed conservative management including fluoroscopically directed caudal epidural injections showed combined pain relief and improvement in functional status in $83 \%$ of the intervention group and 5\% of the control group at the end of a 2-year follow-up. Furthermore, this study also showed that patients receiving approximately six procedures over a period of 2 years experienced 78 weeks of relief, significantly different than the patients undergoing caudal epidural injections.
The results of this study illustrate the mechanism of percutaneous adhesiolysis with delivery of steroids and hypertonic sodium chloride solution to the targeted area to be superior to caudal epidural steroid injections. The defined purpose of percutaneous epidural lysis of adhesions is to eliminate the deleterious effects of scar formation, with target delivery of high concentrations of injected drugs. The postulated mechanism of epidural fibrosis as a causative factor in failed back surgery syndrome includes neurological disturbances secondary to mechanical tethering of nerve roots, disturbances in blood flow, irritation of exposed dorsal root ganglion, and nerve root adherence to the underlying discs and pedicle. ${ }^{22-28}$ Adhesiolysis provides the advantage of target delivery and uninterrupted action of local anesthetics, steroids, and hypertonic sodium chloride solution. While corticosteroids have been shown to reduce inflammation by inhibiting the synthesis of a number of proinflammatory mediators, ${ }^{69-72}$ local anesthetics also have been described to provide short- to

血 3 months 田 6 months 12 months $\square 18$ months 24 months

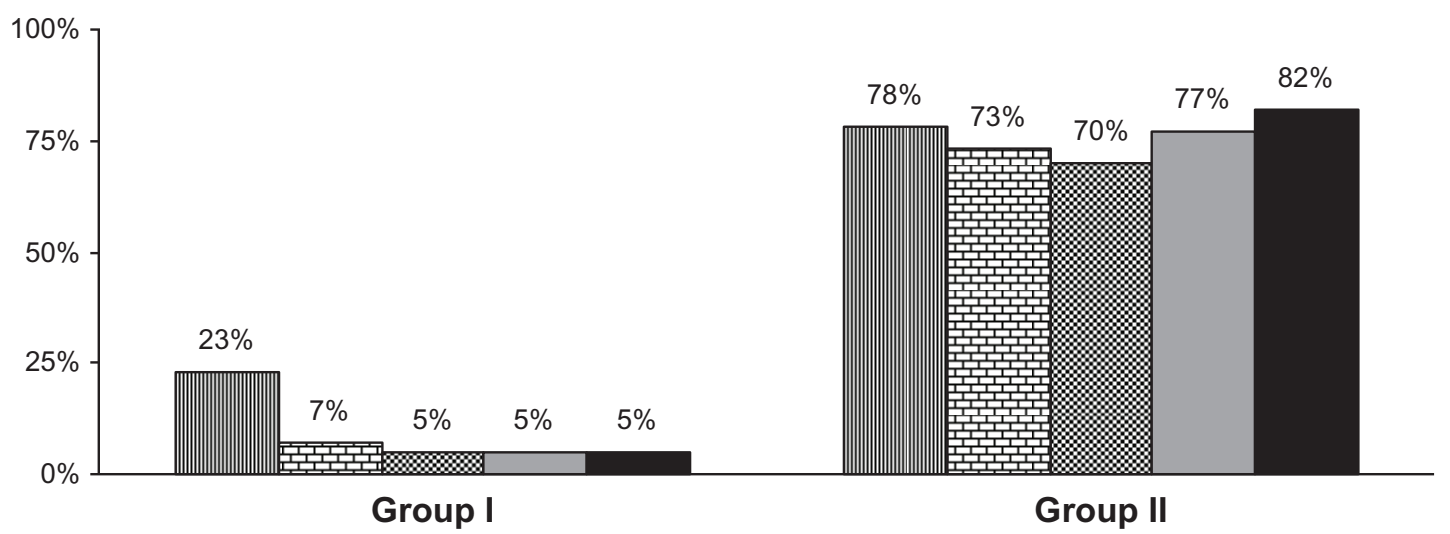

Figure 2 Proportion of patients with significant relief $(\geq 50 \%)$ in average pain score (Numeric Rating Scale and Oswestry Disability Index). 
Table 4 Employment characteristics

\begin{tabular}{|c|c|c|c|c|c|c|}
\hline & \multicolumn{3}{|l|}{ Group I } & \multicolumn{3}{|l|}{ Group II } \\
\hline & Baseline & 12 months & 24 months & Baseline & 12 months & 24 months \\
\hline \multicolumn{7}{|l|}{ Employment status } \\
\hline Employed part-time & 3 & 3 & 3 & I & 1 & I \\
\hline Employed full-time & 6 & 6 & 6 & 4 & 4 & 4 \\
\hline Unemployed & 3 & 3 & 3 & 0 & 0 & 0 \\
\hline Total employed & 9 & 9 & 9 & 5 & 5 & 5 \\
\hline Eligible for employment & 12 & 12 & 12 & 5 & 5 & 5 \\
\hline Housewife & 4 & 4 & 4 & I & 1 & I \\
\hline Disabled & 28 & 28 & 28 & 42 & 41 & 41 \\
\hline$>65$ years of age & 16 & 16 & 16 & 12 & 13 & 13 \\
\hline Total number of patients & 60 & 60 & 60 & 60 & 60 & 60 \\
\hline
\end{tabular}

Notes: There were no changes in Group I; one disabled became $>65$ years of age in Group II.

long-term symptomatic relief based on various mechanisms, including separation of nociceptive discharge, block of the sympathetic reflex arc and sensitization, anti-inflammatory effect, and blockade of axonal transport of nerve fibers. ${ }^{73-78}$ In addition, hypertonic sodium chloride solution has been shown to provide analgesia and neurolysis. ${ }^{41,42}$

The results of this evaluation are superior to previous evaluations. ${ }^{15,79}$ In contrast to the previous evaluations which provided modest results, this follow-up evaluation on a long-term basis of 2 years showed $82 \%$ of the patients with significant improvement in pain and function with approximately six procedures over a period of 2 years. Even so, multiple reports have been published in favor of and against percutaneous adhesiolysis. ${ }^{15,19,29,40,41,43,44,46-49,79}$ Many of the systematic reviews have been criticized for their methodology by evaluating studies inappropriately, resulting in inaccurate conclusions based on objectionable evidence synthesis. ${ }^{15,19,29,30,36,47-49}$ Helm et al provided a synthesis of multiple issues related to evidence assessment of percutaneous adhesiolysis. ${ }^{15}$ This study may be criticized for inadequate double-blinding, lack of a placebo group, and a high proportion of patient withdrawals in the control group.

Table 5 Daily opioid (morphine equivalents)

\begin{tabular}{llc}
\hline & Group I & Group II \\
\hline Baseline & $69.6 \pm 106.8$ & $99.0 \pm 117.1$ \\
3 months & $68.0 \pm 91.4$ & $76.6^{*} \pm 99.8$ \\
6 months & $67.9 \pm 91.4$ & $75.1^{*} \pm 97.5$ \\
I2 months & $67.9 \pm 91.4$ & $78.2^{*} \pm 103.7$ \\
I8 months & $67.9 \pm 91.4$ & $76.3^{*} \pm 96.5$ \\
24 months & $67.9 \pm 91.4$ & $76.3^{*} \pm 96.5$ \\
Group difference & & 0.149 \\
Baseline versus follow-up points & \multicolumn{2}{c}{0.089} \\
Group by time interaction & \multicolumn{2}{c}{0.485} \\
\hline
\end{tabular}

Notes: *Significant difference with baseline values $(P<0.05)$; ${ }^{\text {there }}$ was significant difference between groups at 3 months, 6 months, 12 months, 18 months, and 24 months.
Patient blinding was considered adequate as patients were mixed together with other patients and the only occasion where blinding was not followed was in the control group, due to the placing of the catheter without adhesiolysis at S3. The chances of this confounding the results are minimal as all other personnel and patients were blinded. With interventional techniques, the design difficulties inherent in avoiding placebo and nocebo effects are a difficult venture. Present methodology appears to be the best way to provide a control group with caudal epidural injections in patients who have already failed caudal epidural injections. A new placebo design appears to have been evolving with passing the catheter subcutaneously, the feasibility and results of which need to be seen. This study with active-control with local anesthetic and steroids without adhesiolysis is considered appropriate due to the increasing influence of comparative effectiveness research in modern medicine. Furthermore, this study will provide generalizability and external validity better than a placebo-controlled trial. Placebo-control has major disadvantages. It has also been shown that the injection of inactive substances into active structures elicits various types

Table 6 Characteristics of weight monitoring

\begin{tabular}{llll}
\hline Weight (Ibs) & $\mathbf{n}=\mathbf{6 0}$ & P-value \\
\cline { 2 - 3 } & Group I & Group II & \\
\hline Weight at beginning & $185 . I \pm 44.0$ & $177.6 \pm 49.1$ & 0.377 \\
Weight at I year & $184 . I \pm 42.8$ & $175.9 \pm 48 . I$ & 0.324 \\
Change & $-1.0 \pm 6.7$ & $-1.7 \pm 12.7$ & 0.713 \\
Lost weight & $33 \%(20)$ & $42 \%(25)$ & \\
No change & $45 \%(27)$ & $22 \%(13)$ & $\mathbf{0 . 0 2}$ I \\
Gained weight & $22 \%(13)$ & $37 \%(22)$ & \\
Weight at 2 years & $184.4 \pm 42.4$ & $176.2 \pm 49.0$ & 0.332 \\
Change & $-0.7 \pm 7.2$ & $-1.3 \pm 16.6$ & 0.798 \\
Lost weight & $33 \%(20)$ & $45 \%(27)$ & \\
No change & $44 \%(26)$ & $17 \%(10)$ & $\mathbf{0 . 0 0 6}$ \\
Gained weight & $23 \%(14)$ & $38 \%(23)$ & \\
\hline
\end{tabular}

Notes: Data expressed as mean \pm standard deviation or $\%(n)$; bold indicates significance. 
of therapeutic or nontherapeutic effects similar to placebo and nocebo reactions. ${ }^{80-90}$ However, there are numerous difficulties related to having a placebo group in interventional technique studies. Placebo experimentation continues to yield variable results. The results have shown that an injection of an inactive compound to an active structure can produce multiple types of reactions and for those methodologists who lack an understanding of placebo and nocebo in clinical trials, this may lead to confusion and the mistaken sense that they all look alike. ${ }^{82-90}$ Properly controlled placebo trials have, however, shown appropriate results.

The withdrawal of a significant proportion of patients prematurely from the study is a major issue specifically for methodologists. However, in patients with chronic intractable pain providing interventions that are nonresponsive is ethically compromising. Moreover, patients cannot be expected to wait 2 years to find out if additional treatments are available for them or not. This is a practical issue related to all types of studies involving interventions specifically with placebo-control.

This is a practical clinical trial, which differs from placebo-controlled trials. In the modern era of evidencebased medicine and comparative effectiveness research, practical clinical trials are considered more appropriate than exploratory trials or efficacy trials. The differences between placebo-controlled trials and active-controlled trials include the fact that placebo-controlled trials measure absolute effect size and show the existence of effect, whereas activecontrolled trials, such as the present study, not only show the existence of effect, but compare the therapies. ${ }^{91}$

In summary, the evidence in this report demonstrates that in postsurgery patients with chronic function limiting low back and/or lower extremity pain, percutaneous adhesiolysis with hypertonic sodium chloride solution injection may provide on average 78 weeks of relief over a period of 2 years with approximately six procedures per 2 years or three procedures per year.

\section{Conclusion}

This study evaluated the effectiveness of percutaneous adhesiolysis in post lumbar surgery syndrome, demonstrating significant improvement in $82 \%$ of patients with pain relief and a functional status of $50 \%$ compared to the control group receiving caudal epidural injections, where improvement was seen in only $5 \%$ of patients at the 2-year follow-up.

\section{Disclosure}

The authors report no conflicts of interest in this work.

\section{References}

1. Tosteson AN, Tosteson TD, Lurie JD, et al. Comparative effectiveness evidence from the spine patient outcomes research trial: surgical versus nonoperative care for spinal stenosis, degenerative spondylolisthesis, and intervertebral disc herniation. Spine (Phila Pa 1976). 2011;36(24): 2061-2068.

2. Deyo RA, Mirza SK, Martin BI, Kreuter W, Goodman DC, Jarvik JG. Trends, major medical complications, and charges associated with surgery for lumbar spinal stenosis in older adults. JAMA. 2010;303(13): 1259-1265.

3. Davis H. Increasing rates of cervical and lumbar spine surgery in the United States, 1979-1990. Spine (Phila Pa 1976). 1994;19(10): 1117-1123.

4. Hu RW, Jaglal S, Axcell T, Anderson G. A population-based study of reoperations after back surgery. Spine (Phila Pa 1976). 1997;22(19): 2265-2270.

5. Malter AD, McNeney B, Loeser JD, Deyo RA. 5-year reoperation rates after different types of lumbar spine surgery. Spine (Phila Pa 1976). 1998;23(7):814-820.

6. Keskimaki I, Seitsalo S, Osterman H, Rissanen P. Reoperations after lumbar disc surgery: a population-based study of regional and interspecialty variations. Spine (Phila Pa 1976). 2000;25(12):1500-1508.

7. Waddell G, Kummel EG, Lotto WN, Graham JD, Hall H, McCulloch JA. Failed lumbar disc surgery and repeat surgery following industrial injuries. J Bone Joint Surg Am. 1979;61(2):201-207.

8. Ross JS, Robertson JT, Frederickson RC, et al; ADCON-L European Study Group. Association between peridural scar and recurrent radicular pain after lumbar discectomy: magnetic resonance evaluation. Neurosurgery. 1996;38(4):855-861.

9. Fritsch EW, Heisel J, Rupp S. The failed back surgery syndrome: reasons, intraoperative findings, and long-term results: a report of 182 operative treatments. Spine (Phila Pa 1976). 1996;21(5): 626-633.

10. Osterman H, Sund R, Seitsalo S, Keskimaki I. Risk of multiple reoperations after lumbar discectomy: a population-based study. Spine (Phila Pa 1976). 2003;28(6):621-627.

11. Law JD, Lehman RA, Kirsch WM. Reoperation after lumbar intervertebral disc surgery. J Neurosurg. 1978;48(2):259-263.

12. Rajaee SS, Bae HW, Kanim LE, Delamarter RB. Spinal fusion in the United States: analysis of trends from 1998 to 2008. Spine (Phila Pa 1976). 2012;37(1):67-76.

13. Martin BI, Mirza SK, Flum DR, et al. Repeat surgery after lumbar decompression for herniated disc: the quality implications of hospital and surgeon variation. Spine J. 2012;12(2):89-97.

14. Deyo RA, Martin BI, Kreuter W, Jarvik JG, Angier H, Mirza SK. Revision surgery following operations for lumbar stenosis. J Bone Joint Surg Am. 2011;93(21):1979-1986.

15. Helm S 2nd, Benyamin RM, Chopra P, Deer TR, Justiz R. Percutaneous adhesiolysis in the management of chronic low back pain in post lumbar surgery syndrome and spinal stenosis: a systematic review. Pain Physician. 2012;15(4):E435-E462.

16. Parr AT, Manchikanti L, Hameed H, et al. Caudal epidural injections in the management of chronic low back pain: a systematic appraisal of the literature. Pain Physician. 2012;15(3):E159-E198.

17. Simopoulos TT, Manchikanti L, Singh V, et al. A systematic evaluation of prevalence and diagnostic accuracy of sacroiliac joint interventions. Pain Physician. 2012;15(3):E305-E344.

18. Hansen H, Manchikanti L, Simopoulous TT, et al. A systematic evaluation of the therapeutic effectiveness of sacroiliac joint interventions. Pain Physician. 2012;15(3):E247-E278.

19. Manchikanti L, Boswell MV, Singh V, et al. Comprehensive evidence-based guidelines for interventional techniques in the management of chronic spinal pain. Pain Physician. 2009;12(4):699-802.

20. Manchikanti L, Manchukonda R, Pampati V, Damron KS, McManus CD. Prevalence of facet joint pain in chronic low back pain in postsurgical patients by controlled comparative local anesthetic blocks. Arch Phys Med Rehabil. 2007;88(4):449-455. 
21. Brzezicki G, Jankowski R, Blok T, Klimczak A, et al. Postlaminectomy osteopontin expression and associated neurophysiological findings in rat peridural scar model. Spine (Phila Pa 1976). 2011;36(5):378-385.

22. Ronnberg K, Lind B, Zoega B, et al. Peridural scar and its relation to clinical outcome: a randomised study on surgically treated lumbar disc herniation patients. Eur Spine J. 2008;17(12):1714-1720.

23. Almeida DB, Prandini MN, Awamura Y, et al. Outcome following lumbar disc surgery: the role of fibrosis. Acta Neurochir (Wien). 2008; 150(11):1167-1176

24. Jou IM, Tai TW, Tsai CL, Tsai TM, Yung WS, Jung YC. Spinal somatosensory evoked potential to evaluate neurophysiologic changes associated with postlaminotomy fibrosis: an experimental study. Spine (Phila Pa 1976). 2007;32(19):2111-2118.

25. Alkalay RN, Kim DH, Urry DW, Xu J, Parker TM, Glazer PA. Prevention of postlaminectomy epidural fibrosis using bioelastic materials. Spine (Phila Pa 1976). 2003;28(15):1659-1665.

26. Ozer AF, Oktenoglu T, Sasani M, et al. Preserving the ligamentum flavum in lumbar discectomy: a new technique that prevents scar tissue formation in the first 6 months postsurgery. Neurosurgery. 2006;59(1 Suppl 1):ONS126-ONS133.

27. Cooper RG, Freemont AJ, Hoyland JA, et al. Herniated intervertebral disc-associated periradicular fibrosis and vascular abnormalities occur without inflammatory cell infiltration. Spine (Phila Pa 1976). 1995;20(5):591-598.

28. Schimizzi AL, Massie JB, Murphy M, et al. High-molecular-weight hyaluronan inhibits macrophage proliferation and cytokine release in the early wound of a preclinical postlaminectomy rat model. Spine $J$. 2006;6(5):550-556.

29. Massie JB, Huang B, Malkmus S, et al. A preclinical post laminectomy rat model mimics the human post laminectomy syndrome. $J$ Neurosci Methods. 2004;137(2):283-289.

30. Haq I, Cruz-Almeida Y, Siqueira EB, Norenberg M, Green BA, Levi AD. Postoperative fibrosis after surgical treatment of the porcine spinal cord: a comparison of dural substitutes. Invited submission from the Joint Section Meeting on Disorders of the Spine and Peripheral Nerves, March 2004. J Neurosurg Spine. 2005;2(1):50-54.

31. Abbott ZI, Nai KV, Allen RR, Akuthota VR. Utilization characteristics of spinal interventions. Spine J. 2012;12(1):35-43.

32. Manchikanti L, Pampati V, Boswell MV, Smith HS, Hirsch JA. Analysis of the growth of epidural injections and costs in the Medicare population: a comparative evaluation of 1997, 2002, and 2006 data. Pain Physician. 2010;13(3):199-212.

33. Manchikanti L, Pampati V, Falco FJ, Hirsch JA. Growth of spinal interventional pain management techniques: analysis of utilization trends and Medicare expenditures 2000 to 2008. Spine (Phila Pa 1976). July 11, 2012. [Epub ahead of print.]

34. Manchikanti L, Singh V, Cash KA, Pampati V, Datta S. Management of pain of post lumbar surgery syndrome: one-year results of a randomized, double-blind, active controlled trial of fluoroscopic caudal epidural injections. Pain Physician. 2010;13(6):509-521.

35. Manchikanti L, Singh V, Cash KA, Pampati V, Datta S. A comparative effectiveness evaluation of percutaneous adhesiolysis and epidural steroid injections in managing lumbar post surgery syndrome: a randomized, equivalence controlled trial. Pain Physician. 2009;12(6):E355-E368.

36. Manchikanti L, Singh V, Cash KA, Pampati V, Damron KS, Boswell MV. A randomized, controlled, double-blind trial of fluoroscopic caudal epidural injections in the treatment of lumbar disc herniation and radiculitis. Spine (Phila Pa 1976). 2011;36(23):1897-1905.

37. Manchikanti L, Cash RA, McManus CD, Pampati V, Fellows B. Fluoroscopic caudal epidural injections with or without steroids in managing pain of lumbar spinal stenosis: one year results of randomized, doubleblind, active-controlled trial. J Spinal Disord Tech. 2012;25(4):226-234.

38. Manchikanti L, Cash KA, McManus CD, Pampati V, Smith HS. One-year results of a randomized, double-blind, active controlled trial of fluoroscopic caudal epidural injections with or without steroids in managing chronic discogenic low back pain without disc herniation or radiculitis. Pain Physician. 2011;14(1):25-36.
39. Manchikanti L, Pampati V, Cash KA. Protocol for evaluation of the comparative effectiveness of percutaneous adhesiolysis and caudal epidural steroid injections in low back and/or lower extremity pain without post surgery syndrome or spinal stenosis. Pain Physician. 2010;13(2):E91-E110.

40. Yousef AA, EL-Deen AS, Al-Deeb AE. The role of adding hyaluronidase to fluoroscopically guided caudal steroid and hypertonic saline injection in patients with failed back surgery syndrome: a prospective, doubleblinded, randomized study. Pain Pract. 2010;10(6):548-553.

41. Racz GB, Heavner JE, Trescot A. Percutaneous lysis of epidural adhesions - evidence for safety and efficacy. Pain Pract. 2008;8(4): 277-286.

42. Racz GB, Day MR, Heavner JE, et al. Epidural lysis of adhesions and percutaneous neuroplasty. In: Racz GB, Noe CE, editors. Pain Management: Current Issues and Opinions. New York, NY: InTech; 2012:337-370.

43. Manchikanti L, Falco FJ, Boswell MV, Hirsch JA. Facts, fallacies, and politics of comparative effectiveness research: part 1. Basic considerations. Pain Physician. 2010;13(1):E23-E54.

44. Manchikanti L, Falco FJ, Boswell MV, Hirsch JA. Facts, fallacies, and politics of comparative effectiveness research: part 2. Implications for interventional pain management. Pain Physician. 2010;13:E55-E79.

45. Manchikanti L, Falco FJ, Benyamin RM, Helm S 2nd, Parr AT, Hirsch JA. The impact of comparative effectiveness research on interventional pain management: evolution from Medicare Modernization Act to Patient Protection and Affordable Care Act and the Patient-Centered Outcomes Research Institute. Pain Physician. 2011;14:E249-E282.

46. Manchikanti L, Datta S, Derby R, Wolfer LR, Benyamin RM, Hirsch JA. A critical review of the American Pain Society clinical practice guidelines for interventional techniques: part 1. Diagnostic interventions. Pain Physician. 2010;13(3):E141-E174.

47. Manchikanti L, Datta S, Gupta S, et al. A critical review of the American Pain Society clinical practice guidelines for interventional techniques: part 2. Therapeutic interventions. Pain Physician. 2010; 13(4):E215-E264.

48. Chou R, Atlas SJ, Loeser JD, Rosenquist RW, Stanos SP. Guideline warfare over interventional therapies for low back pain: can we raise the level of discourse? J Pain. 2011;12(8):833-839.

49. Manchikanti L, Benyamin RM, Falco FJ, Caraway DL, Datta S, Hirsch JA. Guidelines warfare over interventional techniques: is there a lack of discourse or straw man? Pain Physician. 2012;15(1):E1-E26.

50. Altman DG, Schulz KF, Moher D, et al; CONSORT Group. The revised CONSORT statement for reporting randomized trials: explanation and elaboration. Ann Intern Med. 2001;134(8):663-694.

51. Manchikanti L, Benyamin RM, Helm S, Hirsch JA. Evidence-based medicine, systematic reviews, and guidelines in interventional pain management: part 3. Systematic reviews and meta-analyses of randomized trials. Pain Physician. 2009;12(1):35-72.

52. Fairbank JC, Pynsent PB. The Oswestry Disability Index. Spine (Phila Pa 1976). 2000;25(22):2940-2952.

53. Manchikanti L, Singh V, Falco FJ, Cash KA Fellows B. Comparative outcomes of a 2-year follow-up of cervical medial branch blocks in management of chronic neck pain: a randomized, double-blind controlled trial. Pain Physician. 2010;13(5):437-450.

54. Manchikanti L, Singh V, Falco FJ, Cash KA, Pampati V. Evaluation of lumbar facet joint nerve blocks in managing chronic low back pain: a randomized, double-blind, controlled trial with a 2-year follow-up. Int J Med Sci. 2010;7(3):124-135.

55. Manchikanti L, Singh V, Falco FJ, Cash KA, Pampati V, Fellows B. Comparative effectiveness of a one-year follow-up of thoracic medial branch blocks in management of chronic thoracic pain: a randomized, double-blind active controlled trial. Pain Physician. 2010;13(6): $535-548$.

56. Manchikanti L, Cash KA, Pampati V, Wargo BW, Malla Y. Cervical epidural injections in chronic discogenic neck pain without disc herniation or radiculitis: preliminary results of a randomized, doubleblind, controlled trial. Pain Physician. 2010;13(4):E265-E278. 
57. Manchikanti L, Cash KA, Pampati V, Wargo BW, Malla Y. The effectiveness of fluoroscopic cervical interlaminar epidural injections in managing chronic cervical disc herniation and radiculitis: preliminary results of a randomized, double-blind, controlled trial. Pain Physician 2010;13(3):223-236.

58. Manchikanti L, Cash KA, McManus CD, Pampati V, Benyamin RM. A preliminary report of a randomized double-blind, active controlled trial of fluoroscopic thoracic interlaminar epidural injections in managing chronic thoracic pain. Pain Physician. 2010;13(6):E357-E369.

59. Manchikanti L, Singh V, Falco FJ, Cash KA, Pampati V. Evaluation of the effectiveness of lumbar interlaminar epidural injections in managing chronic pain of lumbar disc herniation or radiculitis: a randomized double-blind, controlled trial. Pain Physician. 2010;13(4):343-355.

60. Manchikanti L, Cash KA, McManus CD, Pampati V, Benyamin RM. Preliminary results of a randomized, double-blind, controlled trial of fluoroscopic lumbar interlaminar epidural injections in managing chronic lumbar discogenic pain without disc herniation or radiculitis. Pain Physician. 2010;13(4):E279-E292.

61. Manchikanti L, Cash KA, McManus CD, Damron KS, Pampati V, Falco FJ. Lumbar interlaminar epidural injections in central spinal stenosis: preliminary results of a randomized, double-blind, active control trial. Pain Physician. 2012;15(1):51-63.

62. Manchikanti L, Cash KA, Pampati V, Malla Y. Fluoroscopic cervical epidural injections in chronic axial or disc-related neck pain without disc herniation, facet joint pain, or radiculitis. J Pain Res. 2012;5: 227-236.

63. Manchikanti L, Cash KA, McManus CD, Pampati V, Benyamin R. Fluoroscopic lumbar interlaminar epidural injections in managing chronic lumbar axial or discogenic pain. J Pain Res. 2012;5:301-311.

64. Manchikanti L, Singh V, Cash KA, Pampati V, Falco FJ. The role of fluoroscopic interlaminar epidural injections in managing chronic pain of lumbar disc herniation or radiculitis: a randomized, double-blind trial. Pain Pract. In press 2012.

65. Manchikanti L, Singh V, Falco FJE, Cash KA, Pampati V, Fellows B. The role of thoracic medial branch blocks in managing chronic mid and upper back pain: a randomized, double-blind, active-control trial with a 2-year follow-up. Anesthesiol Res Pract. 2012;2012:585806.

66. Pereira J, Lawlor P, Vigano A, Dorgan M, Bruera E. Equianalgesic dose ratios for opioids. A critical review and proposals for long-term dosing. J Pain Symptom Manage. 2001;22(2):672-687. Narcotic analgesic converter, GlobalRPh Inc. http://www.globalrph.com/narcotic.cgi. Accessed April 7, 2010.

67. Manchikanti L, Rivera JJ, Pampati V, et al. One day lumbar epidural adhesiolysis and hypertonic saline neurolysis in treatment of chronic low back pain: a randomized double blind trial. Pain Physician. 2004;7(2):177-186.

68. Browner WS, Newman TB, Cummings SR, Hulley SB. Estimating sample size and power: the nitty-gritty. In: Hulley SB, Cummings SR, Browner WS, Grady D, Hearst N, Newman TB, editors. Designing Clinical Research: An Epidemiologic Approach, 2nd ed. Philadelphia, PA: Lippincott, Williams \& Wilkins; 2001:65-91.

69. Manchikanti L. Role of neuraxial steroids in interventional pain management. Pain Physician. 2002;5(2):182-199.

70. Byrod G, Otani K, Brisby H, Rydevik B, Olmarker K. Methylprednisolone reduces the early vascular permeability increase in spinal nerve roots induced by epidural nucleus pulposus application. J Orthop Res. 2000; 18(6):983-987.

71. Hayashi N, Weinstein JN, Meller ST, Lee HM, Spratt KF, Gebhart GF. The effect of epidural injection of betamethasone or bupivacaine in a rat model of lumbar radiculopathy. Spine (Phila Pa 1976). 1998;23(8): 877-885.

72. Lee HM, Weinstein JN, Meller ST, Hayashi N, Spratt KF, Gebhart GF. The role of steroids and their effects on phospholipase A2. An animal model of radiculopathy. Spine (Phila Pa 1976). 1998;23(11): 1191-1196.
73. Bhatia MT, Parikh CJ. Epidural-saline therapy in lumbosciatic syndrome. J Indian Med Assoc. 1966;47(11):537-542.

74. Gupta AK, Mital VK, Azmi RU. Observations of the management of lumbosciatic syndromes (sciatica) by epidural saline. J Indian Med Assoc. 1970;54(5):194-196.

75. Wittenberg RH, Greskotter KR, Steffen R, Schoenfeld BL. Is epidural injection treatment with hypertonic saline solution in intervertebral disk displacement useful? (The effect of $\mathrm{NaCl}$ solution on intervertebral disk tissue). Z Orthop Ihre Grenzgeb. 1990;128(2):223-226. German.

76. Pasqualucci A, Varrassi G, Braschi A, et al. Epidural local anesthetic plus corticosteroid for the treatment of cervical brachial radicular pain: single injection verus continuous infusion. Clin J Pain. 2007;23(7):551-557.

77. Pasqualucci A. Experimental and clinical studies about the preemptive analgesia with local anesthetics. Possible reasons of the failure. Minerva Anestesiol. 1998;64(10):445-457.

78. Cassuto J, Sinclair R, Bonderovic M. Anti-inflammatory properties of local anesthetics and their present and potential clinical implications. Acta Anaesthesiol Scand. 2006;50(3):265-282.

79. Heavner JE, Racz GB, Raj P. Percutaneous epidural neuroplasty: prospective evaluation of $0.9 \% \mathrm{NaCl}$ versus $10 \% \mathrm{NaCl}$ with or without hyaluronidase. Reg Anesth Pain Med. 1999;24(3):202-207.

80. Tachihara H, Sekiguchi M, Kikuchi S, Konno S. Do corticosteroids produce additional benefit in nerve root infiltration for lumbar disc herniation? Spine (Phila Pa 1976). 2008;33(7):743-747.

81. Sato C, Sakai A, Ikeda Y, Suzuki H, Sakamoto A. The prolonged analgesic effect of epidural ropivacaine in a rat model of neuropathic pain. Anesth Analg. 2008;106(1):313-320.

82. Carette S, Leclaire R, Marcoux S, et al. Epidural corticosteroid injections for sciatica due to herniated nucleus pulposus. $N \mathrm{Engl} \mathrm{J} \mathrm{Med}$. 1997;336(23):1634-1640.

83. Karppinen J, Malmivaara A, Kurunlahti M, et al. Periradicular infiltration for sciatica: a randomized controlled trial. Spine (Phila Pa 1976). 2001;26(9):1059-1067.

84. Manchikanti L, Giordano J, Fellows B, Hirsch JA. Placebo and nocebo in interventional pain management: a friend or a foe - or simply foes? Pain Physician. 2011;14(2):E157-E175.

85. Smuck M, Levin JH. Re: Manchikanti L, Singh V, Falco FJ, et al. Cervical medial branch blocks for chronic cervical facet joint pain: a randomized, double-blind, controlled trial with one-year follow-up. Spine (Phila Pa 1976). 2008;33:1813-1820. Spine (Phila Pa 1976). 2009;34(10):1116.

86. Indahl A, Kaigle AM, Reikeras O, Holm SH. Interaction between the porcine lumbar intervertebral disc, zygapophysial joints, and paraspinal muscles. Spine (Phila Pa 1976). 1997;22(24):2834-2840.

87. Indahl A, Kaigle A, Reikeras O, Holm S. Electromyographic response of the porcine multifidus musculature after nerve stimulation. Spine (Phila Pa 1976). 1995;20(24):2652-2658.

88. Pham Dang C, Lelong A, Guilley J, et al. Effect on neurostimulation of injectates used for perineural space expansion before placement of a stimulating catheter: normal saline versus dextrose 5\% in water. Reg Anesth Pain Med. 2009;34(5):398-403.

89. Tsui BC, Kropelin B, Ganapathy S, Finucane B. Dextrose 5\% in water: fluid medium for maintaining electrical stimulation of peripheral nerves during stimulating catheter placement. Acta Anaesthesiol Scand. 2005;49(10):1562-1565.

90. Ghahreman A, Ferch R, Bogduk N. The efficacy of transforaminal injection of steroids for the treatment of lumbar radicular pain. Pain Med. 2010;11(8):1149-1168.

91. ICH Expert Working Group. ICH Harmonised Tripartite Guideline: Choice of Control Group and Related Issues in Clinical Trials E10. Geneva: ICH; 2000. Available from: http://www.ich.org/fileadmin/ Public_Web_Site/ICH_Products/Guidelines/Efficacy/E10/Step4/ E10_Guideline.pdf. Accessed November 19, 2012. 
Journal of Pain Research

\section{Dovepress}

\section{Publish your work in this journal}

The Journal of Pain Research is an international, peer-reviewed, open access, online journal that welcomes laboratory and clinical findings in the fields of pain research and the prevention and management of pain. Original research, reviews, symposium reports, hypothesis formation and commentaries are all considered for publication.

The manuscript management system is completely online and includes a very quick and fair peer-review system, which is all easy to use. Visit http://www.dovepress.com/testimonials.php to read real quotes from published authors.

Submit your manuscript here: http://www.dovepress.com/journal-of-pain-research-journal 